Grossowicz, N., Razin, S. \& Rozansky, R. (1955). J. gen. Microbiol. 13, 436-441

\title{
Factors Influencing the Antibacterial Action of Spermine and Spermidine on Staphylococcus aureus
}

\author{
By N. GROSSOWICZ, S. RAZIN ANd R. ROZANSKY \\ Department of Bacteriology and Department of Clinical Microbiology, \\ Hebrew University-Hadassah Medical School, Jerusalem, Israel
}

SUMMARY: Spermine and spermidine inhibited the growth of Staphylococcus aureus under both aerobic and anaerobic conditions. The activity of spermine was decreased by sera of different species; sheep and bovine serum showed most effect. This antagonistic effect was destroyed by heating the sera at $100^{\circ}$ for $30 \mathrm{~min}$. Sodium and potassium also decreased the antibacterial effect of spermine and spermidine. Spermine exerted a bactericidal effect on staphylococci in broth at $37^{\circ}$ and at $6^{\circ}$, but not on washed organisms suspended in buffer at $6^{\circ}$. The dependence of the bactericidal effect of the bases seems to depend on some metabolic activity of the cocci.

The antibacterial action of spermine and spermidine was described previously (Gurevitch, Rozansky, Weber, Brzezinsky \& Eckerling, 1951; Rozansky, Bachrach \& Grossowicz, 1954; Rozansky, Razin \& Grossowicz, 1954); Hirsch \& Dubos (1952) studied the antimycobacterial effect of these substances. According to Hirsch $(1953 a, b)$ spermine itself was not antimycobacterial but a derivative of it, obtained by the action of an oxidase present in sheep and bovine sera, was the active agent. In the present paper evidence is presented that spermine itself is bactericidal against staphylococci.

\section{METHODS}

The technique described previously was used (Rozansky, Bachrach \& Grossowicz, 1954). Spermine tetrahydrochloride and spermidine phosphate (HoffmanLa Roche Inc.) were used. The antistaphylococcal tests were made in Difco nutrient broth. The $\mathrm{pH}$ value of the medium was adjusted by adding sodium hydroxide or hydrochloric acid and was measured by a Beckman $\mathrm{pH}$ meter. Nutrient broth containing increasing twofold dilutions of spermine or spermidine was distributed into $2 \mathrm{ml}$. quantities in $100 \times 12 \mathrm{~mm}$. test tubes. The tubes were plugged with cotton-wool and autoclaved for $20 \mathrm{~min}$. at $15 \mathrm{lb}$./sq.in.

Staphylococcus aureus strain 23 was the main test organism; $0 \cdot 1 \mathrm{ml}$. of a $1 / 10^{4}$ dilution of a $24 \mathrm{hr}$. broth culture was used as inoculum. The tubes were incubated at $37^{\circ}$, unless otherwise specified. The antibacterial activity was expressed as the minimal concentration of spermine or spermidine which caused complete inhibition of growth visible to the naked eye. In experiments to test the bactericidal effect of spermine, a plate count technique was used.

Anaerobic tests were performed in a jar from which the air was evacuated and the remaining oxygen removed by pyrogallol and $\mathrm{NaOH}$; reduced methylene blue was used as indicator of anaerobiosis. 


\section{RESULTS}

\section{Effect of spermine and spermidine under anaerobic conditions}

To test whether the action of spermine and spermidine was affected by oxidative enzymes of the cocci or by the presence of oxygen in the medium, experiments under anaerobic conditions were performed. As Staphylococcus aureus strain 23 grew very poorly under anaerobic conditions, S. aureus, Oxford strain, was used and to obtain better growth, the broth $(\mathrm{pH} 7 \cdot 4)$ was enriched with gluense to $0.5 \%(\mathrm{w} / \mathrm{v})$. A similar experiment under aerobic conditions was run simultaneously.

Spermine and spermidine both showed the same degree of antibacterial activity under aerobic or anaerobic conditions. After $24 \mathrm{hr}$. incubation at $37^{\circ}$, $1.8 \times 10^{-4} \mathrm{M}$-spermine (60 $\mu \mathrm{g}$. spermine tetrahydrochloride $/ \mathrm{ml}$.) and $1.8 \times 10^{-3}$ M-spermidine $(1000 \mu \mathrm{g}$. spermidine phosphate $/ \mathrm{ml}$.) completely inhibited the growth of Staphylococcus aureus, Oxford strain. These results were confirmed in two other similar experiments, and with a different strain of $S$. aureus.

\section{Effect of various unheated and heated sera}

To evaluate any potential antibacterial role of spermine in vivo, it was desirable to investigate the influence of serum on the system. Since serum contains both heat labile components and heat stable components, the action of unheated and of heated sera was examined.

To test the effect of serum on the antistaphylococcal activity of spermine the following procedure was adopted: sera were diluted $\mathbf{1} / \mathbf{4}$ with distilled water and sterilized by Seitz filtration. A parallel series of dilutions of serum was heated in boiling water for $30 \mathrm{~min}$. Serial dilutions of spermine were made in broth containing the equivalent of $5 \%(\mathrm{v} / \mathrm{v})$ of unheated or of heated serum. The $\mathrm{pH}$ value of the final mixtures was adjusted to $7 \cdot 8$. The tubes were inoculated and the results read after incubation at $37^{\circ}$ for $48 \mathrm{hr}$.

The effect of the various sera is indicated in Table 1. All the unheated sera at $5 \%(\mathrm{v} / \mathrm{v})$ antagonized the action of spermine; sheep and bovine sera decreased the activity 16- and 8-fold, respectively; guinea-pig and rabbit sera were much less active; the sample of human serum showed an intermediate effect. On the other hand, heated sera (human, sheep, guinea-pig, rabbit) did not affect the action of spermine; only the heated bovine serum retained a little antagonistic activity.

To simulate conditions in the animal body more closely, the effect of undiluted serum was tested. Samples of sera of the same species were pooled, sterilized by Seitz filtration and put into tubes, the first receiving $1.8 \mathrm{ml}$., and the following tubes $1 \mathrm{ml}$. of serum. Spermine tetrahydrochloride was added to the first tube to give a final concentration of $2 \mathrm{mg} . / \mathrm{ml}$; d decreasing concentrations of spermine were then obtained in successive tubes by transferring $1 \mathrm{ml}$. amounts from one tube to the next. All tubes were inoculated, and the results are read after $48 \mathrm{hr}$. of incubation at $37^{\circ}$. The results are shown in Table 1. Undiluted serum of man, guinea-pig and rabbit decreased the 
antibacterial activity of spermine against Staphylococcus aureus slightly, as compared with sheep and bovine serum; 60-125 $\mu \mathrm{g}$. spermine.4HCl/ml. being inhibitory in the sera of man, guinea-pig and rabbit, while $c .10$ times this amount of spermine was necessary to inhibit growth in sheep and bovine sera.

Table 1. The effect of heated and unheated sera of various species in annulling the toxicity of spermine for Staphylococcus aureus

Inoculum used: $c .10^{4}$ organisms $/ \mathrm{ml}$. Heated serum was serum diluted $1 / 4$ with distilled water and heated for $30 \mathrm{~min}$. in boiling water. All media were adjusted to $\mathrm{pH} 7 \cdot \mathbf{8}$. Final concentration of sera $5 \%(\mathrm{v} / \mathrm{v})$.

The results were read after $48 \mathrm{hr}$. incubation at $37^{\circ}$, a positive inhibitory effect on growth meaning no growth of the test organism visible to the naked eye. The coefficient of inhibition of spermine activity by added serum (last column) is the degree of decrease in spermine activity as compared with the control without added serum $(=1) ; 16=16$-fold decrease, etc.

$\begin{array}{ccc}\text { Sera added to medium } & \begin{array}{c}\text { Minimal concentration } \\ \text { of spermine.4HCl } \\ \text { which inhibited } \\ \text { growth in presence } \\ \text { of serum }(\mu \mathrm{g} \text {./ml.) }\end{array} & \begin{array}{c}\text { Coefficient of } \\ \text { inhibition of } \\ \text { spermine activity } \\ \text { by serum }\end{array} \\ \text { Sheep } & 500 & \\ \text { Bovine } & 250 & 16 \\ \text { Rabbit } & 60 & 8 \\ \text { Guinea-pig } & 60 & 2 \\ \text { Human } & 125 & 2 \\ \text { Heated } & & 4 \\ \text { Sheep } & 30 & 1 \\ \text { Bovine } & 60 & 2 \\ \text { Rabbit } & 30 & 1 \\ \text { Guinea-pig } & 30 & 1 \\ \text { Human } & 30 & 1\end{array}$

\section{Action of spermine on staphylococci suspended in buffer}

While some antibacterial agents affect multiplying organisms only, spermine and spermidine have been shown to be bactericidal at $37^{\circ}$ and at $6^{\circ}$ (Rozansky, Bachrach \& Grossowicz, 1954; Rozansky, Razin \& Grossowicz, 1954). This killing effect was tested on organisms suspended in a nutrient medium in which even at $6^{\circ}$ metabolic activities might still proceed to some extent. The effect of spermine on washed cells suspended in buffer was therefore tested. A $24 \mathrm{hr}$. broth culture of the staphylococcus was centrifuged, the organisms washed three times and diluted with saline to $1 / 10^{4} ; 1 \mathrm{ml}$. of this suspension was added to $10 \mathrm{ml}$. of either Sørensen buffer $(\mathrm{m} / \mathbf{1 5}, \mathrm{pH} \mathrm{7 \cdot 8)}$ or broth adjusted to $\mathrm{pH} \mathrm{7 \cdot 8.} \mathrm{Spermine} \mathrm{was} \mathrm{added} \mathrm{to} \mathrm{both} \mathrm{series} \mathrm{to} \mathrm{a} \mathrm{concentration} \mathrm{of} 3 \times 10^{-4} \mathrm{M}$, and controls without spermine were included. The suspensions were kept at $6^{\circ}$ and after the intervals indicated in Fig. 1 the surviving organisms were counted by plating. From Fig. 1 it can be seen that organisms in broth + spermine at $6^{\circ}$ died rapidly, with only $2 \%$ surviving after $6 \mathrm{hr}$. and practically none at $24 \mathrm{hr}$., but there was almost no bactericidal effect on organisms kept in buffer + 
spermine. On prolonged incubation (72 hr.) a decrease of about $50 \%$ was noticed in the control tubes and no greater mortality occurred in buffer + spermine.

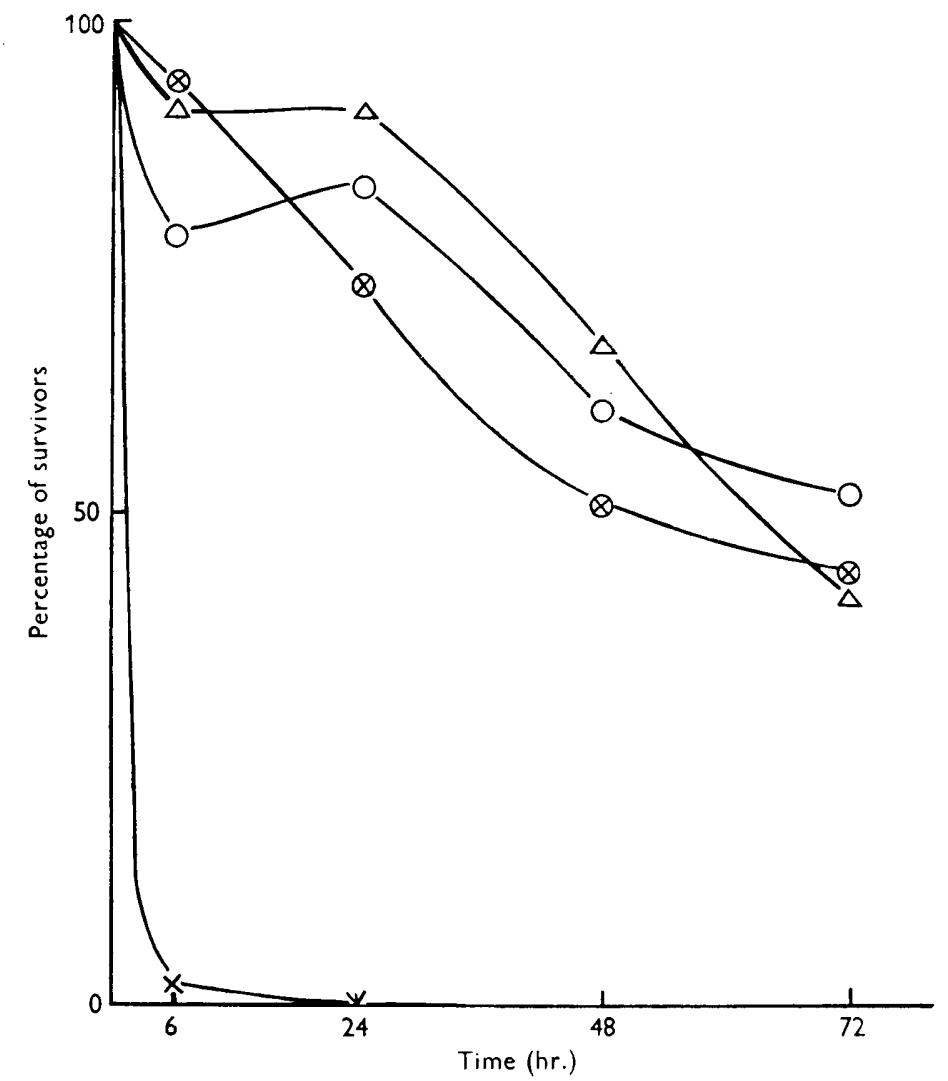

Fig. 1. Effect of spermine on washed cells of Staphylococcus aureus at $6^{\circ}$. The $\mathrm{pH}$ value of all media was 7.8. The number of surviving bacteria was determined by plate count. Initial inoculum c. $10^{5}$ cells $/ \mathrm{ml}$. $-\times-$, cells suspended in Difeo nutrient broth + spermine. $4 \mathrm{HCl} 100 \mu \mathrm{g} . / \mathrm{ml}$; $-\otimes-$, cells suspended in phosphate buffer + sperm. ine. $4 \mathrm{HCl} 100 \mu \mathrm{g} . / \mathrm{ml}$.; $-\triangle$-, cells suspended in Difco nutrient broth (no spermine); - - O-, cells suspended in phosphate buffer (no spermine).

\section{Influence of sodium and potassium chlorides}

Spermine and spermidine are bases and act probably at anionic sites on the bacterial cell. The effect of sodium and potassium ions on the action of spermine and spermidine was therefore examined. Increasing concentrations of sodium chloride, potassium chloride, sodium phosphate or sodium sulphate, were made in broth and twofold dilutions of spermine and spermidine were provided. Table 2 shows that the salts antagonized the antibacterial action of spermine and spermidine. A 10-fold increase in the concentration of sodium chloride was accompanied by a 32 -fold decrease of spermine, and an 8- to 16-fold decrease of spermidine activity. Potassium chloride antagonized the effects of spermine and spermidine in the same way. 
Table 2. Minimal molar concentrations of spermine and spermidine which inhibit growth of Staphylococcus aureus in Difco nutrient broth containing various concentrations of sodium and potassium salts

The $\mathrm{pH}$ value of the medium was 7.7. Size of inoculum: $c .10^{4}$ cells $/ \mathrm{ml}$. Results were read after $48 \mathrm{hr}$. incubation at $37^{\circ}$. Inhibition means no visible growth.

\begin{tabular}{|c|c|c|c|c|c|c|c|c|}
\hline \multirow{2}{*}{$\begin{array}{c}\text { Concentra- } \\
\text { tion of salt } \\
(\%, w / v)\end{array}$} & \multicolumn{2}{|c|}{$\mathrm{NaCl}$} & \multicolumn{2}{|c|}{$\mathbf{K C l}$} & \multicolumn{2}{|c|}{$\mathrm{Na}_{2} \mathrm{HPO}_{4} \cdot 12 \mathrm{H}_{2} \mathrm{O}$} & \multicolumn{2}{|c|}{$\mathrm{Na}_{2} \mathrm{SO}_{4}$} \\
\hline & Spermine & Spermidine & $\begin{array}{l}\text { Spermine } \\
\text { linimal con }\end{array}$ & $\begin{array}{l}\text { Sperm } \\
\text { centrat }\end{array}$ & $\begin{array}{l}\text { Spermine } \\
\text { which inh }\end{array}$ & $\begin{array}{l}\text { Spermidine } \\
\text { bited growth }\end{array}$ & Spermine & Spermidine \\
\hline 0.25 & $4.5 \times 10^{-5}$ & & & & & $4.5 \times 10^{-4}$ & & $2.2 \times 10^{-4}$ \\
\hline 0.5 & $4.5 \times 10^{-5}$ & $4.5 \times 10^{-4}$ & $4.5 \times 10^{-5}$ & $4.5 \times 10^{-4}$ & & & $4.5 \times 10^{-5}$ & $4.5 \times 10^{-4}$ \\
\hline 1 & $1.8 \times 10^{-4}$ & $4.5 \times 10^{-4}$ & $1.8 \times 10^{-4}$ & $1.8 \times 10^{-3}$ & $7.5 \times 10^{-4}$ & $1.8 \times 10^{-3}$ & $3.6 \times 10^{-4}$ & $9 \times 10^{-4}$ \\
\hline $\mathbf{2} \cdot \mathbf{5}$ & $1.5 \times 10^{-3}$ & $1.8 \times 10^{-3}$ & $1.5 \times 10^{-3}$ & $3.7 \times 10^{-3}$ & $1.5 \times 10^{-3}$ & $3.7 \times 10^{-3}$ & $1.5 \times 10^{-3}$ & $3.7 \times 10^{-3}$ \\
\hline
\end{tabular}

\section{DISCUSSION}

Hirsch $(1953 a, b)$ with Mycobacterium tuberculosis found that the antimycobacterial activity of spermine was due, not to the substance itself, but to a derivative of it produced by a thermolabile enzyme, spermine oxidase. This enzyme was present in sheep serum but not in human serum. This enzyme mechanism appears not to operate in the antistaphylococcal action of spermine for the following reasons: (i) The antistaphylococcal tests were performed in an autoclaved medium in which any thermolabile enzyme would have been destroyed. (ii) Spermine and spermidine were active against staphylococci under anaerobic conditions, thus excluding the formation of a derivative activated by oxygen. (iii) Sheep serum was not necessary for the action of spermine and spermidine against staphylococci; on the contrary, serum diminished the antistaphylococcal effect. Sheep and bovine sera exhibited a strong antispermine effect, whereas human, rabbit and guinea-pig sera were considerably less antagonistic. Since the antispermine effect of serum was almost completely destroyed by heating in boiling water for $30 \mathrm{~min}$., it is possible that a protein, perhaps an enzyme, might be responsible for the inactivation of spermine by serum.

Spermine and spermidine are polyamines of pronounced basic reaction and their antibacterial effect may be that of cationic poisons. In this respect they resemble the basic thymus peptide (Hirsch, 1954), polylysine (Katchalski, Bichowski-Slomnitzki \& Volcani, 1953) and triethanolamine and similar amines (MacLeod \& Onofrey, 1954). The antibacterial effect of spermine and spermidine, and of polylysine and triethanolamine, was antogonized by sodium and potassium. This reversal of spermine toxicity might be visualized as a cation exchange whereby the base spermine is replaced by non-toxic sodium and potassium ions (Massart, 1948). The bactericidal effect of spermine and spermidine was not limited to multiplying staphylococci, but there was no bactericidal action on washed staphylococci suspended in phosphate buffer, i.e. there was a clear difference in susceptibility between resting and nonresting organisms. The non-sensitivity of the organisms suspended in buffer 
might be due either to their inability to take up spermine or spermidine in the absence of an energy-yielding substrate, or to the absence of some specific metabolic process capable of being blocked by spermine.

The valuable participation of Dr U. Bachrach in some of the experiments is herewith gratefully acknowledged. This work was supported by a grant from the Hadassah Medical Organization Research Fund. Spermine and spermidine were kindly supplied by Messrs Hoffman-La Roche, Inc., Basle, Switzerland.

\section{REFERENCES}

Gurevitch, J., Rozansky, R., Weber, D., Brzezinsky, A. \& Eckerling, B. (1951). Role of spermine in the inhibition of Staphylococcus aureus by human semen. J. clin. Path. 4, 360.

Hinsch, J. G. (1953a). The essential participation of an enzyme in the inhibition of growth of tubercle bacilli by spermine. J. exp. Med. 97, 327.

Hirsch, J. G. $(1953 b)$. Spermine oxidase; an amine oxidase with specificity for spermine and spermidine. J. exp. Med. 97, 345.

Hirsch, J. G. (1954). Mechanisms involved in the antimycobacterial activity of certain basic peptides. J. exp. Med. 99, 79.

Hirsch, J. G. \& Dubos, R. J. (1952). The effect of spermine on tubercle bacilli. J. exp. Med. 95, 191.

Katchalski, E., Bichowski-Slomnitzki, L. \& Volcani, B. E. (1953). The action of some water-soluble poly-amino acids on bacteria. Biochem. J. 55, 671 .

MacLeod, R. A. \& ONofrey, E. (1954). Cation antagonism of the antibacterial action of amines. J. Biol. Chem. $210,193$.

Massart, L. (1948). Antagonism between basic compounds (spermine, streptomycin) and basic bactericidal substances. Nature, Lond. 162, 779.

Rozansky, R., Bachrach, U. \& Grossowicz, N. (1954). Studies on the antibacterial action of spermine. J. gen. Microbiol. 10, 11.

Rozansky, R., Razin, S. \& Grossowicz, N. (1954). The antibacterial action of Spermidine. Bull. Res. Coun. Israel, 4, 306. 